\title{
The long reach of COVID-19: multilateral policy priorities to limit persistent divergences
}

\author{
Gita Gopinath ${ }^{1} \cdot$ Petya Koeva Brooks ${ }^{1} \cdot$ Malhar Nabar $^{1}$
}

Accepted: 10 December 2021 / Published online: 3 January 2022

(c) The Author(s) under exclusive licence to Editorial Office, Indian Economic Review 2021

\begin{abstract}
After a synchronized deep downturn in 2020, an uneven global recovery is underway. Differences in vaccine access and the size of policy support have shaped crosscountry divergences in the rebound. The disparities in the strength of recovery are expected to persist into the medium term. A concerted multilateral effort is needed to limit these divergences, including through accelerating global access to vaccines, investing in climate change mitigation and adaptation, and ensuring financially vulnerable economies have access to international liquidity.
\end{abstract}

Keywords COVID-19 pandemic $\cdot$ Uneven recovery $\cdot$ Divergences $\cdot$ Multilateral policies $\cdot$ International cooperation

JEL Classification F3 $\cdot \mathrm{I} 1 \cdot \mathrm{O} 5$

\section{Introduction}

The global recovery from the pandemic-induced deep contraction of 2020 continues, but with high uncertainty about future prospects. Swift and effective policy responses have helped prevent worse economic outcomes. However, much remains to be done to subdue the health crisis and strengthen the global recovery-especially with the emergence of the Omicron variant in November 2021.

This article draws on the International Monetary Fund's World Economic Outlook (WEO) to highlight key multilateral policy priorities for ensuring all economies get back on paths of durable recovery. The article begins with a short overview of the nature of the shock and its differential near-term impact across economies. The dual health and economic crisis of 2020 is expected to inflict lasting damage to varying degrees across countries. Following a discussion of the medium-term outlook, the article highlights the main multilateral policy priorities to limit expected

Malhar Nabar

mnabar@imf.org

1 Research Department, IMF, Washington, DC, United States 
divergences across country groups: accelerating global access to vaccines, investing in climate mitigation and adaptation efforts, and ensuring vulnerable economies have unimpeded access to international liquidity.

\section{Policy support and vaccine access shape near-term divergences}

\subsection{An unprecedented, synchronized downturn}

The COVID-19 shock led to a synchronized and rapid collapse in economic activity in the second quarter of 2020 unlike any experienced previously in the global economy-in magnitude and nature. Most recessions see sharp drops in durable goods spending, while consumption of services tends to hold up relatively better. The 2020 downturn was markedly different from the past (Gopinath, 2020a). In the absence of vaccines and effective therapies, lockdowns were needed to slow virus transmission and save lives. An essential investment in public health, the Great Lockdown inevitably induced a historic drop in activity, particularly for contact-intensive services, with an accompanying steep collapse in commodity prices and abrupt tightening of financial conditions (Gopinath, 2020b; IMF, 2020a).

The initial economic impact of lockdowns varied across countries depending on their stringency and on the structure of the economies. Tourism-dependent economies, commodity exporters, and those where contact-intensive sectors (including retail, leisure and hospitality) accounted for a large share of employment were hit particularly hard (IMF, 2020b). The share of tele-workable jobs and the quality of digital infrastructure also affected the nature of the downturn (IMF, 2020a). Some economies were therefore able to adapt better to lockdowns than others.

Within countries, the downturn had differential employment impacts across demographic groups. Young workers, women, and those with relatively lower educational attainment were generally hit particularly hard-in part because they tend to work in contact-intensive sectors that experienced disproportionately large downturns compared to the rest of the economy (IMF, 2021a). Closures of schools, daycares, and assisted living facilities also weighed on employment rates, in particular of women, as care-giving responsibilities created additional demands on prime-age workers [see Bluedorn et al., (2021) for a discussion].

The COVID-19 pandemic thus had a multilayered impact, with its early effects on output and employment varying across countries depending on the severity of the initial health crisis, extent of domestic disruptions due to lockdowns, exposure to the commodity price collapse in the first half of 2020, and reversal of capital flows from frontier and emerging market economies.

\subsection{Strong policy response averted worse outcomes}

The global recovery commenced in the second half of 2020 after lockdowns were eased and on the back of a strong, synchronized policy response. At the national level, monetary and fiscal authorities and financial regulators responded swiftly to 
cushion the impact of the health crisis on the economy. The efforts were directed toward protecting household disposable income, firms' cash flow, and financial sector balance sheets. ${ }^{1}$

The concerted fiscal, monetary, and financial regulatory response helped avert worse outcomes. IMF staff estimates suggest that without the fiscal and financial sector measures the global economic collapse in 2020 would have been about three times worse than occurred (IMF, 2021a).

\subsection{Size of the response varied across countries, depending on available policy space}

In the first 6 months of the crisis, announced direct fiscal support (measured as the sum of foregone revenue and crisis-related spending) in advanced economies amounted to around $10 \%$ of the group GDP. The comparable figures for emerging market middle income economies and low income developing countries were around $3.4 \%$ and $1.6 \%$ (IMF, 2020d; Fig. 1 shows the large gap in announced and implemented support across country groups as of September 2021). Beyond these direct measures, significant additional liquidity support was delivered through equity injections, loans, and credit guarantees-with the overall size similarly varying across country groups (IMF, 2020d).

A rapid multilateral response accompanied national efforts. The IMF, for example, increased access limits to its rapid disbursing facilities, provided debt relief to its most vulnerable members, enhanced its ability to lend through its concessional facilities, and extended assistance through its other facilities. In the first six months of the crisis, the IMF had extended about $\$ 100$ billion in assistance to around 80 countries, of which close to 50 were low income developing countries. By November 2021, the amount had increased to $\$ 168$ billion in assistance to 89 countries, of which 55 were low income developing countries.

\subsection{Vaccines provided a further lift, but unequally}

An additional boost came from the launch of vaccination drives in December 2020. Countries that achieved a rapid rollout and strong take-up of vaccines were generally better placed to prevent their health systems from being strained even as caseloads rose with the worldwide spread of the Delta variant. This allowed for a more robust

\footnotetext{
1 Fiscal authorities provided relief through a range of measures, including transfers to households and firms, tax deferrals, wage subsidies, nutrition assistance, and enhanced unemployment benefits. They also extended credit guarantees to support credit provision. Central banks cut interest rates, launched or expanded asset purchase programs (including, for the first time in some emerging market economies; IMF 2020c), widened the range of eligible collateral and eased access to liquidity facilities. They also entered or activated swap arrangements with other central banks to support foreign currency liquidity provision. Financial regulators introduced a range of measures to support credit intermediation: easing classification guidelines for nonperforming loans, relaxing provisioning requirements for banks, reducing risk weights on loans backed by public guarantees, introducing moratoriums on bankruptcy proceedings, and allowing more flexibility regarding bank capital requirements.
} 
(Revenue and spending measures; percent of 2020 GDP)

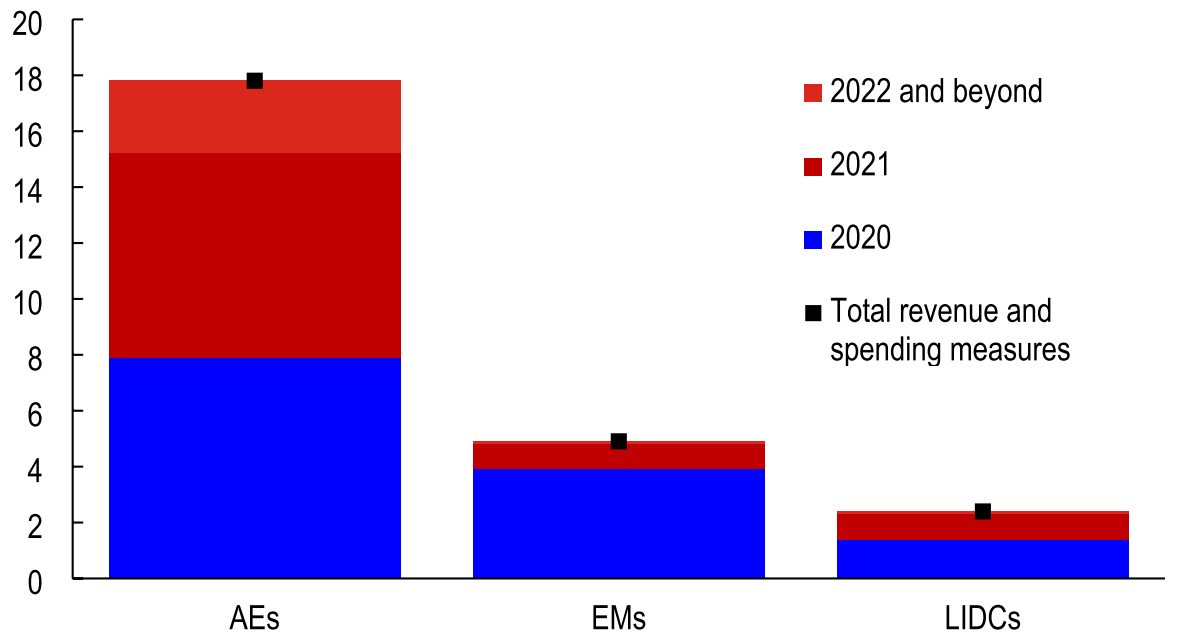

Fig. 1 Government fiscal support in response to COVID-19 across time horizon. Sources: IMF Fiscal Monitor database of Country Fiscal Responses to COVID-19 and IMFstaff estimates

resumption of activity, reinforcing the lift from policy support and the adaptation of work practices to subdued mobility.

The rollout of vaccines remains highly unequal. By November 2021, advanced economies had achieved close to $65 \%$ full vaccination. The corresponding figure for middle-income emerging market economies was $45 \%$. Low income developing countries - many of which rely primarily on collective procurement vehicles such as COVAX - had fully vaccinated less than $10 \%$ of their population (Fig. 2).

\subsection{Speed of the rebound varies across economies}

The two forces of policy support and vaccinations have had a significant impact on the speed of the rebound across countries. As Fig. 3 shows, by end-2021, output in the advanced economy group is projected to be around $1 \%$ below the level forecast prior to the pandemic. The gap between China's end-2021 output level and the pre-pandemic projection is close to $2 \%$. In both cases this reflects, to an important extent, sizable policy support and rapid vaccination which has allowed for an early resumption of activity (IMF, 2021a). For emerging market and developing economies excluding China, the corresponding gap is around $4 \%$ below the pre-pandemic forecast.

\section{Near-term divergences expected to persist into medium term}

A common feature of past recessions is that negative shocks often have persistent effects (Cerra \& Saxena, 2008; Blanchard et al., 2015; IMF, 2018). Output generally tends to remain below the pre-shock trend path for several years-unless an effective 


\section{(Percent of population)}

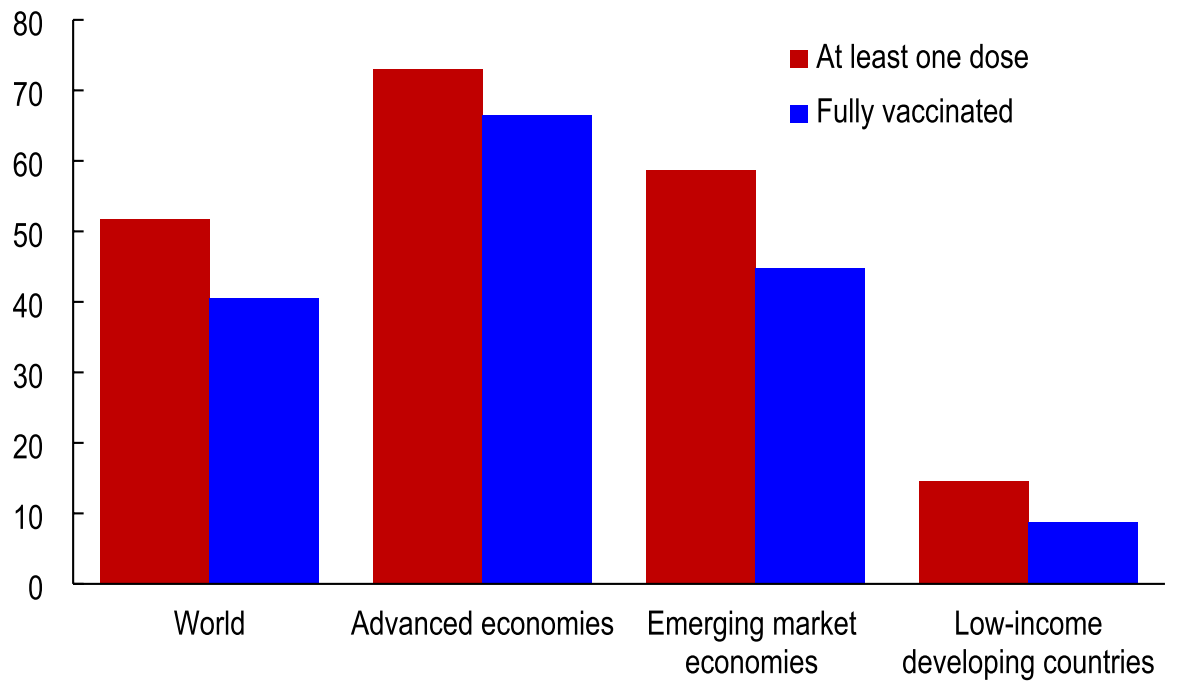

Fig. 2 Vaccination. Sources: Our World in Data; and IMF staff calculations.Note: Data as of November 11,2021

(Index; 2019Q4 = 100)

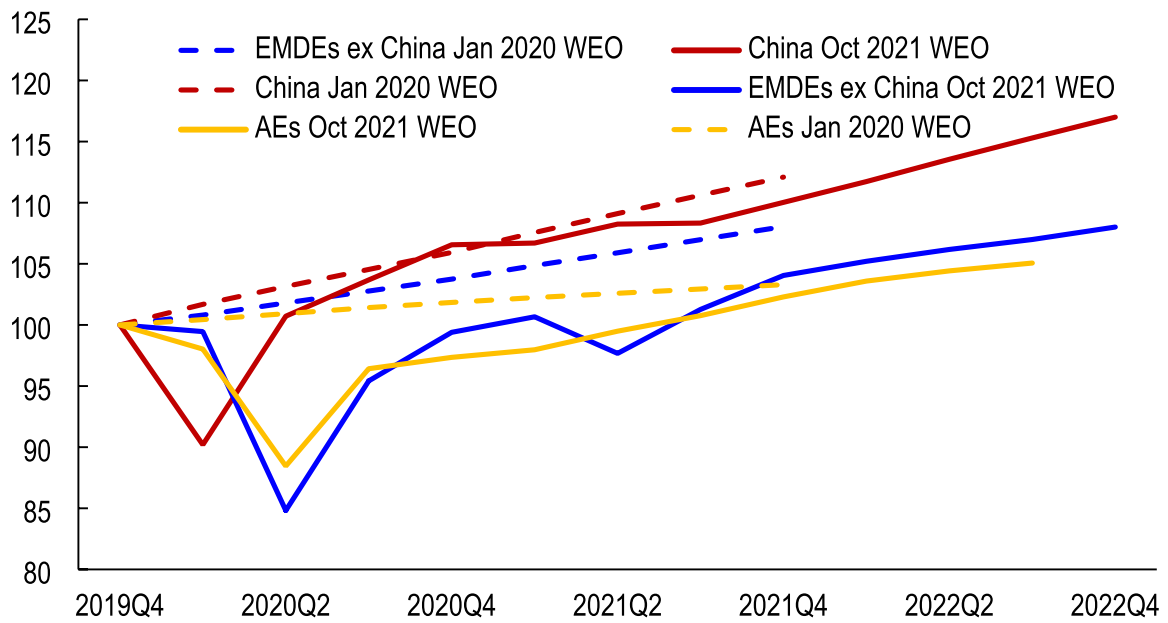

Fig. 3 WEO forecasts for advanced economies and emerging market and developing economies. Sources: October 2021 WEO, January 2020 WEO Update; and IMF staff calculations

counter-cyclical policy response mitigates the initial downturn and creates the conditions for a rapid recovery.

In line with this previous research, the IMF's assessment is that nearterm divergences are expected to persist into the medium term (IMF, 2021b). 


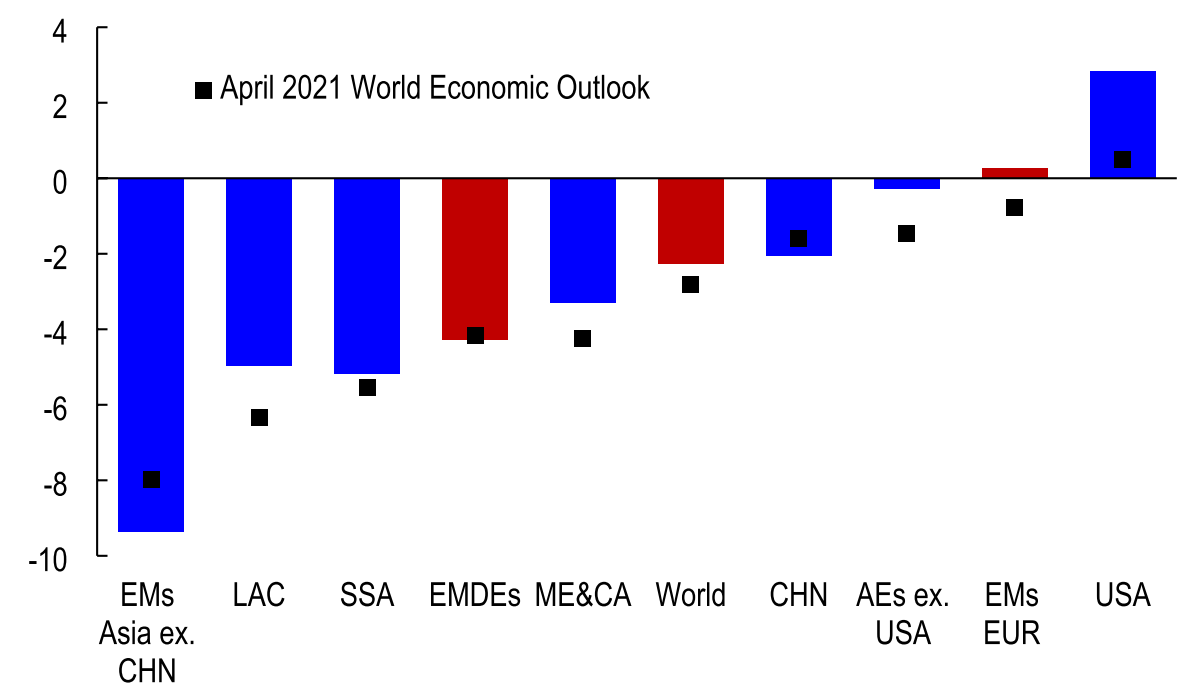

Fig. 4 Output losses relative to pre-pandemic trend, 2024. Sources: October 2021 WEO, April 2021 WEO; and IMF staff calculations.Notes: EMs = Emerging Markets; CHN = China; LAC = Latin America and the Caribbean; SSA = Sub-Saharan Africa; EMDEs = Emerging Market and Developing Economies; ME\&CA = Middle East and Central Asia; AEs = Advanced Economies; EUR = Europe

Advanced economies, on average, are expected to suffer smaller persistent output losses than emerging market middle-income economies and low-income developing countries. Relative to previous forecasts, the divergences across country groups have widened-for instance, when comparing advanced economies with low income developing countries.

For advanced economies, aggregate output is expected to return to the prepandemic projected trend path by 2022. Output is however expected to remain below the pre-pandemic trend path throughout the forecast horizon for the other income groups.

These divergent paths are expected to give rise to large cumulative output effects by the outer years of the forecast window. By 2024, aggregate output in the United States is projected to be close to 3\% above the pre-pandemic forecast ( $0.3 \%$ for the advanced economies excluding the United States), while it is about $4.3 \%$ below the pre-pandemic forecast for the emerging market and developing economy group (Fig. 4). By region, Emerging Asia excluding China is projected to suffer the largest loss, reflecting the lasting impact of the deep contractions and pandemic waves experienced in 2020-21, in particular by India and the ASEAN economies.

The relatively slower recovery in emerging market and developing economies compared to advanced economies also bears on improvements in living standards and per capita income. Some regions have experienced severe absolute declines in per capita GDP and are not expected to regain pre-pandemic levels for several years. Latin America and Middle East and Central Asia regions, for example, are projected to regain their 2019 per capita level only in 2023, and Sub-Saharan Africa in 2024. 
The pattern of anticipated medium-term losses is different from what was seen after the 2008-09 global financial crisis. At that time, advanced economieswhich were at the epicenter of the financial crisis-experienced significantly larger persistent losses than others. Emerging market and developing economies generally staged more robust recoveries. The group benefited at the time from strong growth in China and favorable spillovers to supply-chain economies and commodity exporters (IMF, 2021a).

\subsection{Lasting impacts on employment are expected as well}

COVID-19 delivered a catastrophic hit to employment in 2020, with particularly acute impacts on youth, women, and workers with lower educational attainment. International Labor Organization estimates suggest that the decline in working hours was equivalent to the loss of 255 million full-time jobs worldwide. Emerging market and developing economies were hit hard, with Latin America and the Caribbean and South Asia among the regions experiencing particularly large declines in working hours (ILO, 2021).

The recovery in employment growth has thus far lagged that of output (IMF, 2021b), reflecting health concerns, child-care constraints, and possible labor demand changes related to accelerated automation. With the continued grip of the pandemic on the global economy, the employment recovery is expected to remain subdued-particularly in the case of emerging market and developing economies (Fig. 5). This possibly reflects more limited child-care support in emerging market and developing economies compared to advanced economies, lingering concerns of migrant workers unwilling to seek opportunities far from home and traditional support networks, and less expansive safety nets and training programs to help workers maintain ties with the formal labor force after losing their jobs.

\subsection{Learning losses may leave imprints on long-term growth}

Beyond the medium-term, the COVID-19 crisis may continue to exert a drag on labor market outcomes long after the pandemic has abated. This is because of the widespread closures of educational institutions during the pandemic. Unless remedial measures redress the learning losses that have resulted from school and university closures during the pandemic, affected students face weaker future prospects for securing gainful employment in high value-added jobs. Those individuals' lifetime earnings and economy-wide labor productivity growth are both likely to suffer. As seen in Fig. 6, schools were closed for longer in low income developing countries than elsewhere, raising the possibility of wider gaps in the stock of human capital across income groups in the years to come-another possible force for persistent cross-country divergences in income per capita. 


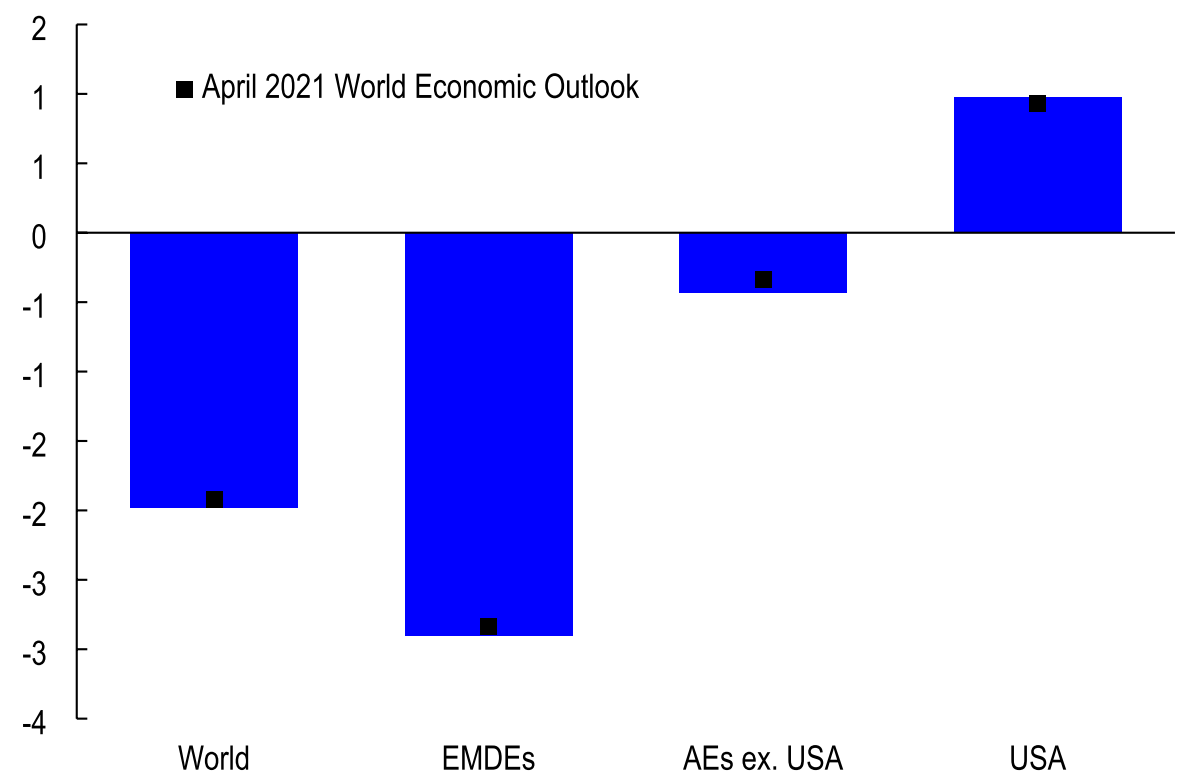

Fig. 5 Employment losses relative to pre-pandemic trend, 2024. Sources: October 2021 WEO, April 2021 WEO; and IMF staff calculations.Notes: EMDEs = Emerging Market and Developing Economies; AEs $=$ Advanced Economies

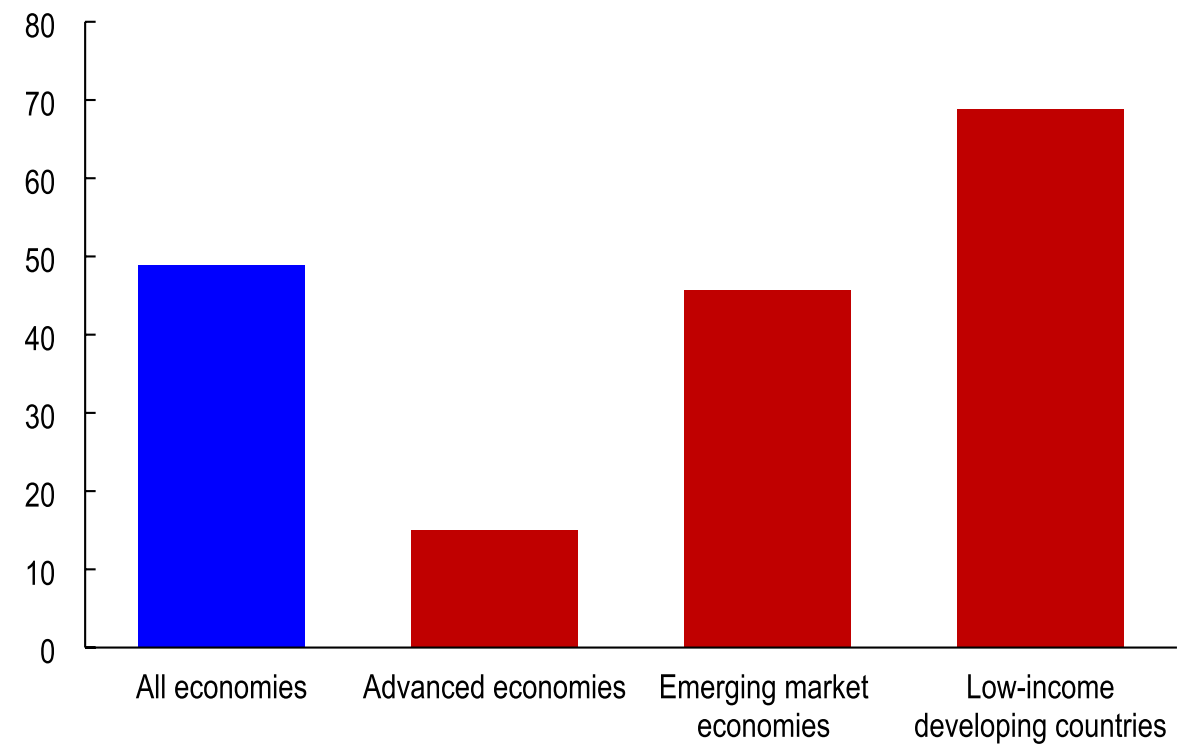

Fig. 6 Global education losses due to the COVID-19 pandemic (Average missed days of instruction in 2020). Sources: UNESCO-UNICEF-World Bank Survey on National Education Responses to COVID-19 School Closures; IMF April 2021 WEO; and IMF staff calculations 


\section{Divergences could widen further than projected}

Among the principal risks to the global outlook are a protracted pandemic (with the possibility of the spread of new variants that evade protection from existing vaccines) and a sudden tightening of financial conditions, for example due to shifts in the outlook for Federal Reserve monetary policy as US wage and price pressures broaden.

The materialization of either of these risks could further widen the gaps in recovery paths between advanced economies and emerging market and developing economies. A protracted pandemic would weigh on strained budgets in emerging market and developing economies, holding back critical social and infrastructure spending with negative consequences for supply potential. Changes in the outlook for US monetary policy could lead to significantly tighter external financial conditions especially for emerging market and developing economies with large external borrowing and dollar funding needs (Adrian \& Gopinath, 2021), which would weigh on their growth outlook.

In addition, there is growing concern about weather-related disasters related to climate change. These events have had larger negative effects in low-income developing countries and small island economies-countries that are among the lowest contributors to global greenhouse gas emissions and are also less equipped to adapt to climate change than larger economies (Pugacheva, 2021).

\section{Multilateral policies to arrest divergences}

As discussed in the preceding sections, following a synchronized downturn the global economy is now experiencing asynchronous recoveries. Vaccine access and policy support are the principal forces shaping divergent recovery paths, with implications for medium-term prospects. Moreover, no country-even those with high vaccination rates-is assured of a durable recovery as long the virus transmits elsewhere and has opportunities to mutate. Continued, concerted multilateral efforts are therefore needed to avert downside risks and strengthen growth prospects for all economies. The priority areas are as follows.

\subsection{Global vaccination}

Efforts to increase access to vaccines, particularly in low-income developing countries, need to be vastly stepped up. The IMF's May 2021 plan to combat the pandemic_-jointly endorsed by the World Health Organization, the World Bank, and the World Trade Organization-lays out targets to vaccinate at least $40 \%$ of the population in every country by end- 2021 and at least $70 \%$ by mid-2022, while also ensuring adequate diagnostics and therapeutics (Agarwal \& Gopinath, 2021). The second target is still within reach. This will require vaccine donations by countries with large shares of their population already vaccinated and a commitment to 
rapidly fulfill the pledges. Vaccine manufacturers should also prioritize deliveries to countries that still lack wide access-including by enhancing supply to collective procurement vehicles such as COVAX. Remaining restrictions on exports of medical equipment, raw materials, and finished vaccines should also be removed. Vaccine production capabilities should be diversified, building on recent partnerships for instance to manufacture mRNA vaccines in Africa. This will help increase global capabilities to accelerate vaccine coverage in underserved areas and for booster doses. Funding for testing and genomic surveillance should be increased, an imperative reinforced by the emergence of Omicron. Further investment in therapeutics is also needed.

\subsection{Climate change: mitigation and adaptation}

Extreme weather-related events across the world in 2021 (including floods in eastern and south Asia and Europe; drought in Brazil; wildfires in Canada and the United States) reinforce the need for urgent actions to reduce the risks of catastrophic health and economic outcomes due to climate change. Existing nationally determined contributions for reducing greenhouse gas emissions fall well below what is required to limit the increase in global temperatures at $2{ }^{\circ} \mathrm{C}$ above pre-industrial averages. At the same time, tax revenue associated with environmental policy has declined as a share of GDP in recent years, while public expenditure on the environment has flattened (IMF, 2021b).

Going beyond commitments announced at the recent United Nations Climate Change Conference (COP26), a multi-pronged effort is needed, comprising: (1) an international carbon price floor adjusted to country-specific circumstances and levels of development; (2) a public investment push in green infrastructure and subsidies for research on renewables and storage technology; and (3) targeted compensatory schemes to support households adversely affected by the green energy transition (IMF, 2020b). Multilateral support via cross-border technology transfer and climate finance initiatives will be essential to ensure that financially constrained countries less able to invest in such mitigation measures can do so as well.

\subsection{Access to international liquidity}

As part of its response to the COVID-19 crisis, the IMF boosted countries' reserve assets through a General Allocation of Special Drawing Rights (SDRs) equivalent to US\$650 billion. Emerging market and developing economies received about $40 \%$ of the allocation. The Fund has also expanded its lending toolkit to include a renewable and replenishable credit line for members with strong policy frameworks and fundamentals. The IMF has also provided new financing through other lending facilities, temporarily increased access limits to its emergency financing facilities, and improved its ability to provide grant-based debt service relief. Other multilateral measures_-including the G20 Debt Service Suspension Initiative (DSSI)—are helping countries conserve international liquidity and avoid even larger cuts to essential social and health spending (IMF, 2021b). Several emerging market and developing 
economies-low-income countries in particular-will require continued support from the international community. Liquidity relief may not prove sufficient for economies with unsustainable sovereign debt or large financing needs. The Common Framework for Debt Treatments beyond the DSSI endorsed by the Group of 20 aimed to facilitate orderly debt restructuring. Implementation has been too slow, however, and urgent improvements are needed (Georgieva \& Pazarbasioglu, 2021).

Beyond these three priorities, cooperation will need to be enhanced on other fronts: continued removal of increased trade restrictions that came into force in 2018-19, resolving the impasse over World Trade Organization Appellate Body appointments, defusing cross-border technology tensions, and implementing the recently agreed global minimum for corporate taxes.

Failure to address these cross-border, overarching imperatives runs the risk of creating additional roadblocks in what is already a difficult global recovery path. Concerted multilateral cooperation along these dimensions, by contrast, can reinforce the impact of national policy initiatives, strengthen prospects for a durable global recovery from the COVID-19 shock, and limit divergences in living standards across countries.

\section{References}

Adrian, T., \& Gopinath, G. (2021). Addressing inflation pressures amid an enduring pandemic. https:// blogs.imf.org/2021/12/03/addressing-inflation-pressures-amid-an-enduring-pandemic/. Accessed 7 Dec 2021

Agarwal, R., \& Gopinath, G. (2021). A proposal to end the COVID-19 pandemic. IMF staff discussion note. https://www.imf.org/en/Publications/Staff-Discussion-Notes/Issues/2021/05/19/A-Proposalto-End-the-COVID-19-Pandemic-460263. Accessed 7 Dec 2021

Blanchard, O., Cerutti, E., \& Summers, L. (2015). Inflation and activity-two explorations and their monetary policy implications. NBER working paper 21726. https://www.nber.org/papers/w21726. Accessed 7 Dec 2021

Bluedorn, J.; Francesca, G. C., Niels-Jakob, H.H., Shibata, I., \& Tavares, M. M. (2021). Gender and employment in the COVID-19 recession: Evidence on "She-cessions". IMF Working Paper. https:// www.imf.org/en/Publications/WP/Issues/2021/03/31/Gender-and-Employment-in-the-COVID-19Recession-Evidence-on-She-cessions-50316. Accessed 7 Dec 2021

Cerra, V., \& Saxena, S. (2008). Growth dynamics: the myth of economic recovery. American Economic Review, 98(1), 439-457. https://doi.org/10.1257/aer.98.1.439

Georgieva, K., \& Pazarbasioglu, C. (2021). The G20 common framework for debt treatments must be stepped up. https://blogs.imf.org/2021/12/02/the-g20-common-framework-for-debt-treatmentsmust-be-stepped-up/. Accessed 7 Dec 2021

Gopinath, G. (2020a). Limiting the economic fallout of the coronavirus with large targeted policies. https://blogs.imf.org/2020/03/09/limiting-the-economic-fallout-of-the-coronavirus-with-large-targe ted-policies/. Accessed 7 Dec 2021

Gopinath, G. (2020b). The great lockdown: Worst economic downturn since the great depression. https:// blogs.imf.org/2020/04/14/the-great-lockdown-worst-economic-downturn-since-the-great-depre ssion/. Accessed 7 Dec 2021

International Labor Organization. 2021. ILO monitor: COVID-19 and the world of work. Seventh edition. January 2021. http://www.ilo.org/wcmsp5/groups/public/@dgreports/@dcomm/documents/brief ingnote/wcms_767028.pdf. Accessed 7 Dec 2021

International Monetary Fund. (2018). The global recovery 10 years after the 2008 financial meltdown. Chapter 2, World Economic Outlook, October 2018. https://www.imf.org/en/Publications/WEO/ Issues/2018/09/24/world-economic-outlook-october-2018\#Chapter\%202. Accessed 7 Dec 2021 
International Monetary Fund. (2020a). The great lockdown. World Economic Outlook, April 2020. https://www.imf.org/en/Publications/WEO/Issues/2020/04/14/weo-april-2020\#Chapter\%201. Accessed 7 Dec 2021

International Monetary Fund. (2020b). A long and difficult ascent. World Economic Outlook, October 2020. https://www.imf.org/en/Publications/WEO/Issues/2020/09/30/world-economic-outlook-octob er-2020\#Chapter\%201:\%20Global\%20Prospects\%20and\%20Policies. Accessed 7 Dec 2021

International Monetary Fund. (2020c). Emerging and frontier markets: A greater set of policy options to restore stability. Global Financial Stability Report, October 2020. https://www.imf.org/en/Publicatio ns/GFSR/Issues/2020/10/13/global-financial-stability-report-october-2020\#Chapter2. Accessed 7 Dec 2021

International Monetary Fund. (2020d). Fiscal monitor: Policies for the recovery. October 2020. https:// www.imf.org/en/Publications/FM/Issues/2020/09/30/october-2020-fiscal-monitor. Accessed 7 Dec 2021

International Monetary Fund. (2021a). Managing divergent recoveries. World Economic Outlook, April 2021. https://www.imf.org/en/Publications/WEO/Issues/2021/03/23/world-economic-outlook-april2021. Accessed 7 Dec 2021

International Monetary Fund. (2021b). Recovery during a pandemic: Health concerns, supply disruptions, and price pressures. World Economic Outlook, October 2021. https://www.imf.org/en/Publi cations/WEO/Issues/2021/10/12/world-economic-outlook-october-2021. Accessed 7 Dec 2021

Pugacheva, E. (2021). Who suffers most from climate change? The case of natural disasters. Box 1.2. World Economic Outlook, April 2021. https:/www.imf.org/en/Publications/WEO/Issues/2021/03/ 23/world-economic-outlook-april-2021. Accessed 7 Dec 2021

Publisher's Note Springer Nature remains neutral with regard to jurisdictional claims in published maps and institutional affiliations. 